\title{
PENGISIAN JABATAN KEPALA DAERAH DAN WAKIL KEPALA DAERAH YANG BERHALANGAN TETAP DALAM SISTEM KETATANEGARAAN INDONESIA(STUDI KASUS PENGISIAN JABATAN WAKIL BUPATI KABUPATEN GROBOGAN) ${ }^{1}$
}

\author{
Rahma Aulia ${ }^{2}$, Fifiana Wisnaeni ${ }^{3}$ \\ Program Magister Ilmu Hukum, Fakultas Hukum, Universitas Diponegoro \\ msrahmaaulia@gmail.com
}

\begin{abstract}
The position of vice regent in Grobogan Regency is still not filled. This happened because the elected regent of Grobogan Edy Maryono passed away 3 days before he was appointed vice regent. In summary, the purpose of this paper is to discusses why in Grobogan District until now has not been filled filling Regent Representative Period 2016-202, and to know the mechanism and procedure of filling the position of Vice Regent who is unable to remain. The approach method used in this research is the normative juridical approach. Based on the discussion, the mechanism and procedures for the succession upon the permanently incapacitated vice-regent have been regulated in article 176 Law No. 10 of 2016 on the Election of Governor and ViceGovernor, Regent and Vice-Regent, and Mayor and Deputy Mayor.
\end{abstract}

Keywords: Regent and Vice-Regent, Succession upon the Position, Local Government.

\begin{abstract}
Abstrak
Sampai saat ini jabatan wakil bupati di Kabupaten Grobogan masih belum terisi. Hal tersebut terjadi karena wakil Bupati terpilih Grobogan Edy Maryono meninggal dunia 3 hari sebelum ia dilantik menjadi wakil bupati. Secara ringkas tujuan tulisan ini adalah untuk membahas mengapa di Kabupaten Grobogan sampai saat ini belum dilaksanakan pengisian jabatan Wakil Bupati Periode 2016-2021, dan untuk mengetahui mekanisme dan tata cara pengisian jabatanWakil Bupati yang berhalangan tetap. Metode pendekatan yang digunakan dalam penelitian ini adalah pendekatan yuridis normatif. Berdasarkan pembahasan, sejatinya mekanisme dan tata cara pengisian jabatan Wakil Bupati yang berhalangan tetap telah diatur di dalam Pasal 176 UU No 10 Tahun 2016 tentang Pemilihan Gubernur dan wakil Gubernur, Bupati dan Wakil Bupati dan Walikota dan wakil Walikota.
\end{abstract}

Kata Kunci: Kepala Daerah dan Wakil Kepala Daerah, Pengisian Jabatan, Pemerintahan Daerah

\footnotetext{
${ }^{1}$ Arikel ini merupakan hasil penelitian

${ }^{2}$ Mahasiswa Program Studi Magister Ilmu Hukum Undip

${ }^{3}$ Dosen Program Studi Magister ilmu Hukum Undip 


\section{A. Pendahuluan}

Pemilihan Kepala Daerah yang dilaksanakan secara langsung dipastikan membuka ruang partisipasi politik rakyat untuk mewujudkan kadaulatan dalam menentukan pemimpin di daerah. Karena tujuan ideal pilkada langsung antara lain terpilihnya Kepala Daerah yang terpercaya, memiliki kemampuan, kepribadian dan moral yang baik. Idealnya, Kepala Daerah terpilih adalah orang- orang yang berkenan di hati rakyat, dikenal dan mengeal daera, serta memiliki ikatan emosional kuat terhadap rakyat dan daerah. Selain itu, pilkada langsung juga menjadi semacam training ground, yakni ajang atau arena pelatihan pemimpin dalam rangka menyediakan stok pemimpin untuk tingkatan lebih tinggi (Suharizal, 2011, p. 41).

Dalam sejarah kepemiluan, untuk pertama kalinya Indonesia mengadakan pemilihan umum kepala daerah (Pilkada) secara serentak pada tanggal 9 Desember 2015. Ada 269 daerah terdiri atas 9 provinsi, 36 kota, dan 224 kabupaten yang secara bersama-sama memilih kepala daerahnya pada Pilkada serentak 2015. Hal itu berarti sekitar 53\% dari total 537 jumlah provinsi dan kabupaten/kota di Indonesia melaksanakan pilkada secara serentak (Ananingsih, 2016). Di tahun 2017 ini Indonesia telah melaksanakan pilkada serentak yang ke 2. 101 daerah telah melaksanakan pilkada, dengan rincian pilkada Gubernur di tujuh provinsi yakni Aceh, Bangka Belitung, Banten, DKI Jakarta, Sulawesi Barat, Gorontalo dan Papua Barat. Sementara itu untuk pilkada pemilihan Bupati dan Wakil Bupati akan diadakan di 76 kabupaten dan pilkada Walikota 18 kota.

Pencalonan kepala daerah dilakukan dengan dua jalur yaitu melalui partai politik dan jalur Perseorangan. Mekanisme pencalonan tersebut diatur dalam UndangUndang Nomor 10 Tahun 2016 Tentang Perubahan Kedua Atas Undang-Undang Nomor 1 Tahun 2015 Tentang PenetapanPeraturan Pemerintah Pengganti Undang-Undang Nomor 1 Tahun 2014 TentangPemilihan Gubernur, Bupati, Dan Walikota Menjadi Undang-Undang. Dalam Pasal 42.

Namun bagaimanakah jika kepala daerah khususnya wakil kepala daerah setelah terpilih meninggal dunia? Seperti yang terjadi di Kabupaten Grobogan. Hingga bulan Agustus 2017, jabatan wakil bupati di Kabupaten Grobogan masih belum terisi. Hal tersebut terjadi karena wakil Bupati terpilih Grobogan Edy Maryono meninggal pada 3 hari sebelum ia dilantik menjadi wakil bupati, tepatnya pada hari Jumat 11 Maret 2016. Pasangan Sri Sumarni - Edy Maryono memenangkan Pilkada 
serentak pada 9 Desember 2015. Pasangan itu diusung PDI Perjuangan, Partai Kebangkitan Bangsa, Partai Hanura, dan Partai Amanat Nasional. Sedianya, pasangan itu menjabat hingga 2021.

Pengisian jabatan wakil bupati yang tidak kunjung terisi satu tahun lebih tentunya menimbulkan berbagai pertanyaan. Kabarnya partai koalisi (PDIP, PKB, PAN dan Hanura) yang mengusung pasangan Sri Sumarni-Edy Maryono dalam Pilkada lalu, sampai saat ini belum bisa mencapai kata sepakat. Di sisi lain ada kabar bahwa pengisian jabatan kepala daerah telah sepenuhnya diserahkan kepada partai pengusung Edy Maryono, namun kabarnya belum ada kesiapan dari internal partai.

Melihat luas wilayah daerah grobogan dimana Grobogan merupakan daerah terluas kedua di Jawa Tengah setelah Cilacap, tentunya jika dijalankan oleh Kepala Daerah tanpa dibantu oleh wakilnya tentu membuat sang pemimpin daerah tersebut kewalahan. Kekosongan jabatan wakil bupati tersebut jika terus dibiarkan tentunya juga berdampak terhadap masyarakat dan keadaan daerah. Pengisian jabatan wakil kepala daerah dewasa ini terlihat dianggap sepele dan terkesan berlarut- larut dalam proses pengisiannya oleh pemegang kewenangan yaitu Kepala Daerah bersama dengan DPRD, entah karena faktor kekuasaan atau mungkin saja didominasi dengan faktor lain. Kenyatannya di Kabupaten Grobogan sudah setahun lebih belum menemukan titik temu mengenai penyelesaian pengisian kekosongan jabatan wakil bupati tersebut, padahal ketentuanketentuan didalam perundang- undangan sudah mengatur bagaimana mekanisme dalam pengisian jabatan wakil kepala daerah.

Karena PDIP telah mendapatkan kursi di Bupati maka Sri Sumarni sebagai Bupati telah menyerahkan kepada partai koalisi yaitu PKB, Hanura dan PAN untuk bermusyawarah menentukan 2 kandidat yang nantinya akan dipilih salah 1 sebagai wakil bupati pada rapat paripurna DPRD Kabupaten Grobogan. Perlu diketahui jumlah anggota DPRD Kabupaten Grobogan yaitu 50 kursi, 24 kursi diantaranya berasal dari empat partai koalisi. Yakni PDIP 12 kursi, PKB 7 kursi, Hanura 3 kursi dan PAN 2 kursi. Jika penentuan nama calon pengganti wakil bupati dilakukan melalui voting, penetapan nama wakil bupati rawan gagal dan PKB bisa kehilangan kesempatan untuk menetapkan kadernya menjadi wakil bupati. Isu yang sedang berkembang yaitu ketiga partai koalisi (PKB, PAN dan Hanura) masih belum ada yang mau mengalah. Padahal di dalam Pasal 176 Undang-Undang Nomor 10 Tahun 2016 tentang Perubahan Kedua Atas UndangUndang Nomor 1 Tahun 2015 Tentang 
Penetapan Peraturan Pemerintah Pengganti Undang-Undang Nomor 1 Tahun 2014 Tentang Pemilihan Gubernur, Bupati, Dan Walikota Menjadi Undang-Undang.

Pada ayat $2^{4}$ Undang-Undang Nomor 10 Tahun 2016 tentang Perubahan Kedua Atas Undang-Undang Nomor 1 Tahun 2015 Tentang Penetapan Peraturan Pemerintah Pengganti Undang-Undang Nomor 1 Tahun 2014 Tentang Pemilihan Gubernur, Bupati, Dan Walikota Menjadi Undang-Undang, disebutkan dengan jelas hanya ada 2 nama calon yang nantinya akan dipilih DPRD Kabupaten Grobogan melalui rapat paripurna. Namun apabila melihat kenyataan bahwa ketiga partai koalisi yang belum mencapai hasil musyawarah, maka dimungkinkan sampai tahun 2021 Kabupaten Grobogan tidak mempunyai Wakil Bupati. Padahal kenyataan tersebut tentu akan merugikan bagi kabupaten Grobogan itu sendiri, karena di dalam sistem pemerintahan, wakil kepala daerah diberikan wewenang dan fungsi untuk membantu tugas dan fungsi kepala daerah, wakil kepala

\footnotetext{
${ }^{4}$ Pasal 176 ayat (2) Undang-Undang Nomor 10 Tahun 2016 tentang Perubahan Kedua Atas UndangUndang Nomor 1 Tahun 2015 Tentang Penetapan Peraturan Pemerintah Pengganti Undang-Undang Nomor 1 Tahun 2014 Tentang Pemilihan Gubernur, Bupati, Dan Walikota Menjadi Undang-Undang, berbunyi: Partai Politik atau gabungan Partai Politik pengusung mengusulkan 2 (dua)orang calon Wakil Gubernur, Wakil Bupati, dan Wakil Walikota kepada Dewan Perwakilan Rakyat Daerah melalui Gubernur, Bupati, atau Walikota, untuk dipilih dalam rapat paripurna Dewan Perwakilan Rakyat Daerah.
}

daerah juga mempunyai tanggung jawab terhadap daerah. Oleh sebab itu terdapat tiga permasalahan yang akan dikaji dalam artikel ini. Pertama,mengapa di Kabupaten Grobogan sampai saat ini belum dilaksanakan pengisian jabatan Wakil Bupati Periode 2016-2021?, kedua, bagaimana mekanisme dan tata cara pengisian jabatanWakil Bupati yang berhalangan tetap?, ketiga, bagaimana tindakan dari partai koalisi atau partai pengusung dalam menetapkan kebijakan yang tepat dalam pengisian jabatan wakil bupati yang berhalangan tetap?

\section{Kerangka Teori}

Sistem pemerintahan demokrasi yang dianut oleh Indonesia megalami pasang surut dari masa ke masa dengan berbagai problematikanya. Gambaran tentang apa, bagaimana dan mengapa dari konsep demokrasi dikejar sebagai sebuah mimpi bersama menjadi pertanyaan peradaban yang tidak akan pernah selesai (Budhiati, 2013). Sebagai syarat utama terciptanya sebuah tatanan demokrasi yakni dilaksanakannya pemilihan umum dengan tujuan membentuk perwakilan di dalam pemerintahan.

Di dalam erademokrasi pemilihan umum merupakan bagian dari upaya untuk melaksanakan demokrasi dan kedaulatan rakyat. Pemilu dilakukan agar pemerintahan yang terbentuk merepresentasikan kehendak 
bersama dari segenap elemen kebangsaan untuk membentuk dan melanjutkan konsepsi kenegaraan (Arrsa, 2014). Ketentuan UUD 1945 juga mengarahkan bahwa negara harus memenuhi segala bentuk hak asasi setiap warganya, khususnya berkaitan dengan hak politik warga negara dan secara lebih khusus lagi berkaitan dengan hak pilih setiap warga negara dalam pemilu di Indonesia. Makna dari ketentuan tersebut menegaskan bahwa segala bentuk produk hukum perundangundangan yang mengatur tentang pemilu khususnya mengatur tentang hak pilih warga negara, seharusnya membuka ruang seluasluasnya bagi setiap warga negara untuk menggunakan hak pilihnya dalam pemilu (Respationo, 2013).

Pengisian jabatan negara (staatsorganen, staatsambten) merupakan salah satu unsur penting dalam hukum tata negara (Soemantri, 2006, p. 174). Tanpa diisi dengan pejabat (ambtsdrager), fungsifungsi jabatan negara tidak mungkin dijalankan sebagaimana mestinya. Pengisian jabatan tidak hanya dilakukan sekali namun dilaksanakan secara reguler setiap periode tertentu untuk memilih pejabat pemimpin daerah guna menunjang berjalannya fungsi negara. Tanpa mekanisme pengisian yang jelas, pengisian pemangku jabatan sebagai pelaksana jabatan tidak dapat berjalan. Dalam konsepsi Negara Kesatuan Republik Indonesia selanjutnya disebut (NKRI) yang menerapkan desentralisasi, pengisian jabatan merupakan bentuk pengisian pejabat negara agar pelaksanaan fungsi pemerintahan daerah sebagai bagian dari pemerintahan pusat dapat terlaksana.

Pejabat atau organ dalam birokrasi pemerintah sangat terkait dengan rekrtumen, menurut Miftah Thoha dibagi menjadi dua jenis, yaitu: Pertama, rekrutmen jabatan negara adalah berasal dari kekuatan politik melalui pemilihan umum maupun pengangkatan oleh pejabat politik yang dipilih rakyat. Kedua, Rekrutmen pejabat birokrasi adalah berasal dari pejabat pegawai negeri yang memenuhi persyaratan pemerintah diangkat oleh pejabat yang berhak mengangkatnya (Huda, 2015, p. 8). Penerapan sistem merit (merit system) yaitu adanya kesesuaian antara kecakapan yang dimiliki seorang pegawai dengan jabatan yang dipercayakan kepadanya, meliputi tingkat pendidikan formal, tingkat pendidikan non formal (diklatpim), pendidikan dan latihan teknis, tingkat pengalaman kerja, dan tingkat penguasaan tugas dan pekerjaan (Soemantri, 2006, p. 174). Sedangkan faktor-faktor yang mempengaruhi penerapan sistem merit (merit system) dalam kebijakan promosi jabatan di daerah meliputi regulasi, kontrol eksternal dan komitmen. 


\section{Hasil Penelitian Terdahulu}

Sejauh pengamatan penulis, dengan melakukan penelusuran kepustakaan, internet dan bentuk publikasi lainnya, dijumpai beberapa publikasi mengenai pengisian jabatan kepala daerah, namun dalam penulisan artikel ini memiliki fokus permasalahan tidak dilakukan pengisian jabatan di Kabupaten Grobogan, permasalahan politik partai pengusung kepala daerah dan wakil kepala daerah merupakan fokus utama, karena penyebab tidak dilakukannya pengisian jabatan wakil kepala daerah di kabupaten Grobogan merupakan konsensus bersama oleh Partai politik pengusung kepala daerah dan wakil kepala daerah.

\begin{tabular}{cccl}
\hline No & Peneliti/Penulis & Judul Penelitian & \multicolumn{2}{c}{ Hasil Penelitian } \\
\hline 1 & Bustanuddin, & Analisis Yuridis tentang & Dalam Penelitian ini lebih fokus \\
2011, & Sistem Pengisian Jabatan & pada bahasan pengisian jabatan \\
Universitas & Kepala Daerah yang Ideal & kepala daerah yang diterapkan di \\
Gadjah Mada, & dalam Kerangka Negara & Indonesia, serta memberikan \\
Yogyakarta, & Kesatuan Republik Indonesia & gagasan mengenai sistem pengisian \\
Tesis. & Berdasarkan Undang- & jabatan kepala daerah yang ideal \\
& Undang Dasar Negara & dalam kerangka Negara Kesatuan \\
& Republik Indonesia Tahun & Republik Indonesia. \\
2 & 1945. & Pada penelitian ini lebih membahas \\
Yulia Neta, & Mekanisme Pengisian & perbedaan mekanisme pengisian \\
Jurnal Ilmu & Dabatan Wakil Kepala & jabatan Wakil Bupati Lampung \\
Hukum, & antara Kabupaten Lampung & Tengah dan Lampung Selatan. \\
Volume 4, No. 3 & Selatan dan Kabupaten & Dalam penelitiantersebut juga \\
September- & Lampung Tengah). & membahas kelemahan dan kelebihan \\
Desember 2010. & pengisian jabatan di daerah Lampun \\
& & Tengah dan Lampung Selatan
\end{tabular}

Dari beberapa judul di atas, maka penelitian dengan mengkonstruksikan alasan tidak diisinya kepala daerah di suatu daerah khsusnya di Kabupaten Grobogan belum pernah dilakukan. Penelitian ini sangat penting untuk diteliti dan dikaji, karena didasarkan banyak konflik politik yang berdampak dengan kemajuan suatu daerah. 
Karena tidak diisinya kepala daerah dalam suatu daerah otomatis akan menimbulkan berbagai permasalahan di dalam suatu daerah yang berhubungan dengan berkembangnya daerah tersebut.

\section{B. Metode Penelitian}

Metode pendekatan yang digunakan dalam penelitian ini adalah pendekatan yuridis normatif. Pendekatan yuridis adalah suatu pendekatan yang mengacu pada hukum dan peraturan perundang-undangan yang berlaku (Soemitro, 1982, p. 20), sedangkan pendekatan normatif adalah pendekatan yang dilakukan dengan cara meneliti bahan pustaka atau data sekunder terhadap azas-azas hukum serta studi kasus yang dengan kata lain sering disebut sebagai penelitian hukum kepustakaan (Soekanto \& Mamudji, n.d., p. 13). Dalam hal ini permasalahannya terfokus pada "Pengisian Jabatan Wakil Bupati Kabupaten Grobogan”. Karena itu pendekatan yang akan dikembangkan adalah melakukan kajian secara normatif baik menurut teori maupun ketentuan perundang-undangan. Adapun wawancara terhadap Bupati, para anggota DPRD dan anggota partai politik pendukung serta anggota KPUD hanya sebagai crosscheck data sekunder.Spesifikasi penelitian yang digunakan adalah deskriptif analistis yaitu dengan menggambarkan peraturan perundang-undangan yang berlaku dikaitkan dengan teori hukum dan praktek pelaksanaan hukum positif yang menyangkut permasalahan di atas (Soemitro, 1982, p. 97).

C. Hasil dan Pembahasan

1. Pengisian Jabatan Wakil Bupati Periode 2016-2021 di Kabupaten Grobogan yang Belum Terlaksana.

Tahun 2016, kabupaten Grobogan dipimpin oleh Bupati bernama Sri Sumarni yang resmi dilantik pada tanggal 21 Maret 2016. Namun pelantikan Bupati Grobogan ini dilaksanakan tanpa dibarengi pelantikan Wakil Bupati, dikarenakan Wakil Bupati terpilihyaitu Edy Maryono meninggal 3 (tiga) hari sebelum pelantikan jabatan. Pasangan Bupati dan Wakil Bupati terpilih ini didukung oleh 4 partai koalisi, diantaranya PDI-Perjuangan, PKB, Hanura dan PAN.

Sampai saat ini, Kabupaten Grobogan belum mempunyai wakil pimpinan daerah. Musyawarah yang masih alot dalam partai koalisi ini menyebabkan lamanya pelaksanaan pengisian jabatan Wakil Bupati Grobogan. Apabila partai koalisi tersebut tidak segera menentukan kebijakan, maka diperkirakan Kabupaten Grobogan tidak memiliki wakil pimpinan daerah sampai habis masa jabatannya yaitu pada tahun 2021. 
Belum terisinya jabatan Wakil Bupati di Kabupaten Grobogan, sedikitnya dilatarbelakangi karena dua hal. Pertama, di dalam aturannya Undang-Undang Nomor 10 Tahun 2016 tentang Perubahan Kedua Atas Undang-Undang Nomor 1 Tahun 2015 Tentang PenetapanPeraturan Pemerintah Pengganti Undang-Undang Nomor 1 Tahun 2014 Tentang Pemilihan Gubernur, Bupati, Dan Walikota Menjadi Undang-Undang, hanya dibahas mengenai mekanisme penggantian wakil kepala daerah yang berhalangan tetap. Tidak ada aturan yang menyebutkan keharusan suatu daerah untuk segera menyelenggarakan pengisian jabatan kepala daerah, serta tidak adanya penyebutan sanksi kepada daerah yang tidak segera melaksanakan pengisian jabatan wakil kepala daerah. Oleh karena itu wajar jika banyak daerah yang masih meremehkan hal pengisian jabatan wakil kepala daerah. Kedua, belum terisinya jabatan wakil kepala daerah di Kabupaten Grobogan dilatarbelakangi karena faktor politik.

Menurut beberapa sumber dari anggota DPRD Kabupaten Grobogan bahwa telah terjadi kebuntuan dalam pembahasan diinternal Partai Kebangkian Bangsa (PKB) 5 . Partai Kebangkitan Bangsa (PKB) melalui Sekretaris Jendral (Sekjen) Dewan Pimpinan Pusat (DPP) Partai Kebangkitan Bangsa (PKB) telah mengeluarkan rekomenasi nama

\footnotetext{
${ }^{5}$ KH.Mustain (dari Fraksi PKB) dan Sriyanto (dari
} Fraksi PPP). (salah satu wakil ketua DPRD Grobogan) untuk menggantikan posisi Edy Maryono sebagai Wakil Bupati. Akan tetapi yang bersangkutan tidak menghendaki dan tetap memilih sebagai Wakil Ketua DPRD Kabupaten Grobogan.

Persoalan tersebut menjadikan problem utama atas pengisian jabatan Wakil Bupati. Sebab penentu utama bagaimana pengisian Jabatan Wakil Bupati dilaksanakan atau tidak,sangat bergantung Partai Kebangkitan Bangsa (PKB). Sebab Partai Kebangkitan Bangsa (PKB) sebagai patai pemenang ke-2 (kedua) setelah PDIPerjuangan ketika berkoalisi dengan PDIPerjuangan yang didukung oleh Partai Amanat Nasional (PAN) dan Partai Hati Nurani Rakyat (Hanura) telah bersepakat untuk posisi bupati diambil PDI-Perjuangan dengan mengajukan Sri Sumarni dan PKB mendapatkan posisi Wakil Bupati dengan mengajukan Edy Maryono. Karena itu ketika kedua pasangan tersebut terpilih sebagai bupati dan wakil bupati dan ternyata ada permasalahan terhadap diri wakil bupati terpilih yaitu Edy Maryono yang berhalangan tetap karena meninggal dunia, maka secara politis itu merupakan hak dari PKB untuk menggantikannya. Sementara PKB melalui Sekretaris Jendral DPP PKB telah menunjuk salah satukader partainya untuk menggantikan posisi wakil bupati yang telah ditinggalkan oleh Edy Maryono 
tidak mau dan lebih memilih sebagai Wakil Ketua DPRD Kabupaten Grobogan. Karena itu posisi Wakil Bupati tetap dibiarkan kosong dan belum ada langkah apapun yang akan dilakukan untuk mengisi jabatan wakil Bupati Kabupaten Grobogan.

Menurut Drs. H. Romli Mubarok, SH, $\mathrm{MH} ;{ }^{6}$ membenarkan bahwa tidak berkenannya pengganti posisi Edy Maryono untuk menjadi wakil bupati dan tetap memilih sebagai Wakil Ketua DPRD Kabupaten Grobogan. Ada beberapa pertimbangan :Pertama : secara stuktural posisi Wakil Ketua DPRD lebih startegis dibanding sebagai wakil bupati. Karena posisi jabatannya sebagai Ketua DPC PKB Kabupaten Grobogan..Sebab didalam ketentuan $\mathrm{PKB}$, ada kebijakan bagi siapa saja yang menjadi Kepala Daerah atau Wakil Kepala Daerah untuk menanggalkan jabatan sebagai Ketua DPW atau DPC PKB.Kedua : secara politis, justru dapat menjaga sinergitas hubungan antara bupati dan DPRD. Sebab posisi calon pengganti Edy Maryono dipandang lebih senior karena telah menjabat 2 kali dari tahun 2009 - 2014 dan 2014 hingga sekarang. Mengingat Ketua DPRD dari PDI-Perjuangan (Agus Siswanto) dipandang masih muda dan belum banyak berpengalaman. Karena itu posisi calon pengganti Edy Maryono dianggap

\footnotetext{
${ }^{6}$ Kordinator Wilayah (Korwil) Kabupaten Grobogan, Dewan Pengurus Wilayah (DPW) PKB

Provinsi Jawa Tengah.
}

strategis untuk memperkuat barisan pimpinan DPRD. Sedangkan 2 orang dari pimpinan DPRD yang lain adalah dari Fraksi Golkar dan Gerindra yang merupakan kompetitor (pesaing) utama karena mengusung calon Bupati dan Wakil Bupati (Icek Baskoro-Sugeng Prasetyo) yang telah dikalahkan oleh Pasangan Bupati dan Wakil Bupati (Sri Sumarni-Edy Maryono) yang menjabat saat ini. Ketiga : ada cost-politik yang harus ditanggung (termasuk biaya kampanye) bagi calon pengganti Edy Maryono sebagai Wakil Bupati. Termasuk beban-beban yang lain khususnya dalam proses menduduki jabatan Wakil Bupati Grobogan.

Untuk menggantikan kedudukan Edy Maryono sebagai Wakil Bupati, sebagaimana telah diketahui, bahwa rekomendasi nama yang dikeluarkan oleh Partai Kebangkitan Bangsa memiliki jabatan sebagai Ketua DPC PKB Kabupaten Grobogan dan sekaligus sebagai Wakil Ketua DPRD Kabupaten Grobogan. Akan tetapi xalon pengganti Edy Maryono tersebut tidak menghendaki dan tetap memilih sebagai Wakil Ketua DPRD Kabupaten Grobogan.

Permasalahan lain, ketika bakal nama calon wakil bupati yang nantiya akan dibahas pada rapat paripurna DPRD Kabupaten Grobogan diserahkan kepada partai Hanura dan PAN tentunya sangat 
merugikan kubu PKB. Karena jelas mayoritas perolehan suara di Kabupaten Grobogan didominasi oleh PDI dan PKB. Jika wakil kemudian yang terpilih dari partai Hanura ataupun PAN, tentunya timbul anggapan suara PKB di Kabupaten Grobogan turun, padahal sebagai partai berlatar belakang islam tentunya sangat berhubungan dengan gambaran penduduk Grobogan yang penduduknya menjunjung tinggi nilai- nilai islam dengan ditandai banyaknya pondok- pondok pesantren yang berdiri di daerah tersebut. Tentu anggapan tersebut akan dirasa melemahkan suara PKB di tahun 2019 pada pemilu mendatang.

Ketua Komisi Pemilihan Umum Daerah Kabupaten Grobogan Afrosin Arif, sudah sering menyampaikan dan menghimbau secara informal kepada partai koalisi dan bupati, bahwa tidak diisinya wakil bupati sampai saat ini tentunya merugikan masyarakat dan daerah. Karena masyarakat melalui APBD telah membiayai pelaksanaan pemilihan Bupati pada Tahun 2016.

Menurut Afrosin Arif sebagi, pengaruh yang langsung dirasa yakni kepada Bupati, dimana agenda Bupati tentunya sangat padat dengan tidak adanya pendamping Bupati, dalam satu hari Bupati bisa mendatangi 4-5 acara untuk kepentingan daerah, tentunya hal tersebut dapat mengganggu jalanya pemerintahan di Kabupaten Grobogan.

Sejatinya Hubungan eksekutif dan legislatif akan dapat berjalan dengan baik atau harmonis karena keduanya dapat memahami kewenangan masing- masing dalam melaksanakan perannya.

Misalnya ketika Bupati mengeluarkan kebijakan subsidi yang cukup besar kepada Rumah Sakit Umum Daerah (RSUD), DPRD mengeluarkan kritik keras serta beberapa nasehat terhadap kebijakan tersebut hal ini atas dasar hasil penyelidikan faktual dan data dari laporan keuangan RSUD dimana neraca anggaran pos pengeluaran dan saldo tidak jelas. Faktor lain (Nuraini, 2006) yang menyebabkan keharmonisan hubungan eksekutif dan legislatif adalah kondisi era reformasi yang menuntut transparasi pemerintahan telah memberikan kesempatan pada LSM-LSM dan media lokal untuk terlibat dalam proses kebijakan pemerintahan dalam rangka memonitor dan memberikan laporan kepada publik mengenai kinerja DPRD dan Bupati sehingga hal tersebut dapat menciptakan sebuah hubungan yang lebih kompleks dan demokratis antara eksekutif dan legislatif.

\section{Mekanisme Pengisian Jabatan Wakil Bupati yang Berhalangan Tetap.}

Posisi wakil kepala daerah sangatlah strategis bila dilihat dari tugas dan fungsi 
kepala daerah yang begitu besar, peran dan fungsi wakil kepala daerah sangat penting dalam pemerintahan lokal. Tentu dalam melaksanakan tugas dan fungsi seorang kepala daerah yang memimpin di tingkat provinsi dan sekaligus pula sebagai wakil pemerintah di tingkat provinsi, keberadaan wakil kepala daerah sangat diperlukan dan sangat urgen dengan melihat tugas dan fungsi kepala daerah yang memiliki 2 fungsi dan tugas sekaligus serta membutuhkan perencanaan yang matang serta tindakan yang cepat pula, namun dalam kenyataan di lapangan tugas dan fungsi wakil kepala daerah tidak terlihat jelas dan tugas dan fungsi wakil kepala derah terkesan kurang berfungsi (Anggraeni, 2016, p. 3).

Namun, perlu diingat dalam hal pengisian jabatan wakil kepala daerah, dilakukan dengan alasan sebagai berikut : a.Meninggal dunia, b.berhenti, c.diberhentikan, yang dimana pengisian kekosongan jabatan Wakil Kepala Daerah hanya akan dilakukan jika sisa masa jabatan yang ditinggalkan tersisa 18 bulan dan calon pengganti jabatan tersebut bersifat terbatas dan harus berasal dan diusulkan Kepala Daerah kedalam sidang Paripurna DPRD berdasarkan hasil pembicaraan dan kesepakatan Kepala Daerah dengan partai politik atau gabungan partai politik pengusungnya yang sebelumnya memenangi
Pemilihan Kepala Daerah (Pilkada) (Wijaya \& Griadhi, 2014).

Sesuai dengan Pasal 176 UndangUndang Nomor 10 Tahun 2016 tentangPerubahan Kedua Atas UndangUndang Nomor 1 Tahun 2015 Tentang PenetapanPeraturan Pemerintah Pengganti Undang-Undang Nomor 1 Tahun 2014 TentangPemilihan Gubernur, Bupati, Dan Walikota Menjadi Undang-Undang, menyebutkan:

1) Dalam hal Wakil Gubernur, Wakil Bupati, dan Wakil Walikota berhenti karena meninggal dunia, permintaan sendiri, atau diberhentikan, pengisian Wakil Gubernur, Wakil Bupati, dan Wakil Walikotadilakukan melalui mekanisme pemilihan oleh DPRD Provinsi atau DPRD Kabupaten/Kota berdasarkan usulan dari Partai Politik atau gabungan Partai Politik pengusung.

2) Partai Politik atau gabungan Partai Politik pengusung mengusulkan 2 (dua)orang calon Wakil Gubernur, Wakil Bupati, dan Wakil Walikota kepada Dewan Perwakilan Rakyat Daerah melalui Gubernur, Bupati, atau Walikota, untuk dipilih dalam rapat paripurna Dewan Perwakilan Rakyat Daerah.

3) Dalam hal Wakil Gubernur, Wakil Bupati, dan Wakil Walikota berasal dari calon perseorangan berhenti karena 
meninggal dunia, permintaan sendiri, atau diberhentikan, pengisian Wakil Gubernur, Wakil Bupati, dan Wakil Walikota dilakukan melalui mekanisme pemilihan masing-masingoleh DPRD Provinsi dan DPRD Kabupaten/Kota berdasarkan usulan Gubernur, Bupati, dan Walikota

4) Pengisian kekosongan jabatan Wakil Gubernur, Wakil Bupati, dan Wakil Walikota dilakukan jika sisamasa jabatannya lebih dari 18 (delapan belas) bulan terhitung sejak kosongnya jabatan tersebut.

5) Ketentuan lebih lanjut mengenai tata cara pengusulan dan pengangkatan calon Wakil Gubernur, calon Wakil Bupati, dan calon Wakil Walikota sebagaimana dimaksud pada ayat (1), ayat (2), ayat (3), dan ayat (4) diatur dalam Peraturan Pemerintah.

\section{Kebijakan Partai Pengusung Dalam} Menetapkan Pengisian Jabatan Wakil Bupati yang Berhalangan Tetap.

Tujuan dari dibentuknya partai politik adalah mengorganisir konflik sosial dan artikulasi kepentingan sosial. Menurut Maklumat 3 November 1945 yakni parpol dibentuk untuk memperkuat perjuangan kita untuk mempertahankan kemerdekaan dan menjamin keamanan masyarakat. Secara umum dapat dikatakan bahwa partai politik adalah suatu kelompok yang terorganisir yang anggota-anggotanya mempunyai orientasi, nilai-nilai dan cita-cita yang sama. Tujuan kelompok ini ialah untuk memperoleh kekuasaan politik dan merebut kedudukan politik (biasanya) dengan cara konstitusionil untuk melaksanakan kebijaksanaan-kebijaksanaan mereka. Selain itu, arah pendirian partai politik dimaksudkan sebagai sarana untuk mengatur aspirasi rakyat dari berbagai golongan. Dengan adanya partai politik, aspirasi aspirasi yang berbeda dijadikan pemikiran dan progam yang sistematis dan teratur untuk di perjuangkan sebagai kebijakan publik. Dengan demikian, partai berfungsi sebagai broker of idea, sekaligus sebagai pelopor bagi masyarakat, serta berfungsi untuk mengelola perbedaan yang ada (Safa'at, 2009, p. 129).

Di antara banyak fungsi demokratisasi oleh parpol, ada lima yang sangat penting: (Meyer, 2013, p. 33)

1. Mengagregasikan kepentingankepentingan dan nilai-nilai dan berbagai kalangan masyarakat.

2. Menjajaki, membuat, dan memperkenalkan kepada masyarakat platform pemilihan umum parpol mereka.

3. Mengatur proses pembentukan kehendak politis ('political will') dengan menawarkan alternatif-alternatif kebijakan yang lebih terstruktur. 
4. Merekrut, mendidik, dan mengawasi staf yang kompeten untuk kantor publik mereka dan untuk menduduki kursi di parlemen.

5. Memasyarakatkan, mendidik, serta menawarkan kepada anggotaanggotanya saluran mana yang efektif bagi partisipasi politik mereka sepanjang masa antarpernilu.

Berangkat dari tujuan partai politik tersebut, tentunya dalam penyelenggaraan roda pemerintahan, partai politik ikut masuk di dalamnya. Seperti halnya permasalahan pengisian jabatan wakil bupati di Grobogan, dimana sampai saat ini partai politik gabungan atau koalisi belum menentukan kebijakan. Belumnya diputuskan kebijakan oleh partai politik pendukung Kepala Daerah terpilih Kabupaten Grobogan tentunya membawa dampak yang cukup terasa bagi daerah.

Seharusnya partai politik yang tergabung dalam koalisi Grobogan hebat menentukan kebijakan sebagai berikut:

Pertama: Menjadikan komitmen dan kesadaran bersama bahwa pasangan Bupati dan Wakil Bupati merupakan satu paket pasangan dalam pencalonan sebagai amanat perundang-undangan khususnya UU Nomor 10 Tahun 2016 Tentang Perubahan Kedua Atas UU Nomor 1 Tahun 2015 Tentang penetapan Pemerintah Pengganti UndangUndang Nomor 1 Tahun 2014 Tentang
Pemilihan Gubernur, Bupati dan Walikota menjadi Undang-Undang dan UU Nomor 23 Tahun 2014 Tentang Pemerintahan Daerah. Karena itu posisi Wakil Bupati dipandang sangat penting yang diposisikan sebagai pembantu bupati dalam melaksanakan tugas dan tanggung jawab dalam penyelenggaraan pemerintahan daerah di Kabupaten Grobogan khususnya dalam meningkatkan kesejahteraan rakyat di Kabupaten Grobogan. Untuk itu persoalan-persoalan politik khususnya bagi partai koalisi pengusung pasangan Bupati dan Wakil Bupati (Sri-Edy) jangan sampai mengalahkan kepentingan masyarakat yang sangat berharap agar penyelenggaraan pemerintahan daerah di Kabupaten Grobogan dapat berjalan secara maksimal utamanya dalam meningkatkan kesejahteraan masyarakat.Kedua: Persoalan politik internal PKB yang menjadi akar persoalan belum dilakukan pengisian jabatan Wakil Bupati Kabupaten Grobogan agar tidak mengembangkan kepentingan personal tetapi bagaimana agar memperhatikan kepentingan masyarakat (utamanya pemilih Edy Maryono) dan harapan konstituen Partai Kebangkitan Bangsa (PKB) yang mendambakan kebangggaan karena memiliki Wakil Bupati.

Telah dipahami sebagaian pengurus PKB bahwa calon pengganti Edy Maryono, telah direkomendasikan oleh DPP PKB 
untuk menjadi pengganti Edy Maryono sebagai Wakil Bupati tetapi yang bersangkutan tidak berkenan dan memilih menjadi Wakil Keua DPRD Kabupaten Grobogan dengan pertimbangan baik dari aspek stuktural, aspek politis maupun aspek cost-politik. Aspek stuktural karena menjadi Wakil Ketua DPRD juga menjadi Ketua DPC PKB Kabupaten Grobogan. Sehingga akan kehilangan jabatan sebagai Ketua DPC PKB Kabupaten Grobogan bila menduduki jabatan wakil bupati. Sedang dari politis, justru dapat menjaga sinergitas hubungan antara bupati dan DPRD. Sebab posisi calon pengganti Edy Maryono tersebut dipandang lebih senior yang memiliki penguasaan dan pengalaman sebagai pimpinan DPRD karena telah menjabat 2 kali dari tahun 2009 - 2014 dan 2014 hingga sekarang. Bahkan calon pengganti Edy Maryono tersebut dapat menjadi penjaga tingkat persaingan dengan pimpinan yang lain dari Fraksi Golkar dan Fraksi Gerindra yang sebelumnya Partai Golkar dan Partai Gerindra mengusung calon Bupati dan Wakil Bupati (Icek Baskoro-Sugeng Prasetyo) yang telah dikalahkan oleh Pasangan Bupati dan Wakil Bupati (Sri Sumarni-Edy Maryono) yang menjabat saat ini. Adapun dari aspek costpolitik yaitu harus menanggung biaya yang telah dikeluarkan oleh Edy Maryono (termasuk biaya kampanye) bagi calon pengganti Edy Maryono sebagai Wakil
Bupati. Termasuk beban-beban yang lain khususnya dalam proses menduduki jabatan Wakil Bupati Grobogan.

Kenyataan tersebut merupakan persoalan politik yang hanya memperhatikan kepentingan personal yang sedang memiliki kekuasaan. Karena itu sudah seharusnya para pimpinan partai atau para pimpinan dan anggota DPRD Kabupaten Grobogan berfikir dan bersikap sebagai negarawan yang berorientasi pada kepatingan masyarakat atau kepentingan pemerintahan daerah Kabupaten Grogogan. Karena itu Partai Kebangkitan Bangsa (PKB) atau Partai Koalisi harus mengambil kebijakan terhadap pengisian jabatan Wakil Bupati Kabupaten Grobogan yang berhalangan tetap karena telah meninggal dunia.

Kebijakan tersebut dilakukan karena mepertimbangkan baik dari aspek legalitas regulasi yang mengamanatkan bahwa pencalonan sebagai bupati dan wakil bupati adalah satu paket, juga karena tuntutan masyarakat khususnya konstituen PKB agar proses penyelenggaraan pemerintahan di Kabupaten Grobogan dapat berjalan secara maksimal utamanya dalam peningkatan kesejahteraan masyarakat. Tentunya bila tidak dibantu oleh Wakil Bupati, maka tugas dan tanggung jawab bupati menjadi beban yang cukup berat.

Ada beberapa langkah yang perlu dipertimbangkan oleh Partai Kebangkitan 
bangsa (PKB) atau partai koalisi pengusung Bupati dan Wakil Bupati (Sri-Edy) terpilih.Pertama :Menyiapkan kader dari Partai Kebangkitan Bangsa (PKB) yang telah disepakati oleh Bupati Sri Sumarni dan partai koalisi (Partai Amanat Nasional dan Partai Hanura). Tentunya dengan persyaratan-persyaratan yang harus ditanggung oleh calon pengganti baik yang menyangkut komitmen politik maupun costpolitik sepanjang dapat dirasionalisasi.Kedua : Apabila opsi yang pertama tidak dapat dipenuhi, maka langkah berikutnya menawarkan kepada pihak partai koalisi baik dari Partai Amanat Nasional (PAN) maupun dari Partai Hati Nurani Rakyat (Hanura) untuk menyiapkan calon pengganti sebagai calon Wakil Bupati Grobogan dengan persyaratan sebagaimana opsi yang pertama yaitu disetujui Bupati Sri Sumarni dan mengganti cost-politik yang telah dikeluarkan oleh (alm) Edy Maryono. Tentunya penawaran untuk menyiapkan calon pengganti Wakil Bupati kepada partai koalisi lebih mengutakan partai yang kursinya atau jumlah suaranya lebih banyak.Ketiga : Apabila opsi yang pertama dan kedua tidak terpenuhi, maka perlu mengambil dari pihak luar (non partai koalisi) yaitu dari masyarakat yang independen dan tidak sebagai anggota partai politik atau tidak memiliki keberpihakan kepada partai politik. Seperti pegawai negeri yang berpengalaman (yang dapat diproses pensiun) atau pihak-pihak yang memiliki ketokohan dan pengalaman. Tentunya mereka yang disiapkan telah mendapatkan kesepakatan dari partai koalisi pengusung, utamanya dari Partai Kebangkitan Bangsa (PKB) sebagai partai yang memiliki hak prioritas.

Langkah-langkah untuk mengambil kebijakan tersebut tentu tidak boleh ditundatunda. Sebab untuk mendapatkan kesepakatan tidak mudah dan memerlukan proses dan waktu yang cukup panjang. Apalagi ketentuan perundangan mengatur, tidak dapat dilakukan pengisian jabatan wakil bupati yang berhalangan tetap karena mininggal dunia, apabila masa jabatannya tersisa 18 bulan.

\section{Simpulan dan Saran}

Dari beberapa hal yang telah penulis uraikan, maka dapat ditarik kesimpulan sebagai berikut:

1. Kekosongan jabatan Wakil Bupati di Kabupaten Grobogan akibat meninggalnya Edy Maryono sebagai Wakil Bupati terpilih dikarenakan oleh dua hal. Pertama, di dalam aturannya Undang-Undang Nomor 10 Tahun 2016 tentang Perubahan Kedua Atas Undang-Undang Nomor 1 Tahun 2015 Tentang PenetapanPeraturan Pemerintah Pengganti Undang- 
Undang Nomor 1 Tahun 2014 Tentang Pemilihan Gubernur, Bupati, Dan Walikota Menjadi Undang-Undang, hanya dibahas mengenai mekanisme penggantian wakil kepala daerah yang berhalangan tetap. Tidak ada aturan yang menyebutkan keharusan suatu daerah untuk segera menyelenggarakan pengisian jabatan kepala daerah, serta tidak adanya penyebutan sanksi kepada daerah yang tidak segera melaksanakan pengisian jabatan wakil kepala daerah. Oleh karena itu wajar jika banyak daerah yang masih meremehkan hal pengisian jabatan wakil kepala daerah. Kedua, belum terisinya jabatan wakil kepala daerah di Kabupaten Grobogan dilatarbelakangi karena faktor politik. Pasangan Sri - Edy diusung 4 Partai Politik yaitu Partai Demokrasi Indonesia Perjuangan (PDI-P),Partai Kebangkitan Bangsa (PKB), partai Amanat Nasional (PAN) dan Partai Hati Nurani Rakyat (Hanura).

2. Mekanisme dan tata cara pengisian jabatan Wakil Bupati yang berhalangan tetap akibat meninggal dunia sebagaimana dialami oleh Edy Maryono, SH,MM, telah diatur dalam Undang- Undang Nomor 10 Tahun 2016 tentang Pemilihan Gubernur dan wakil Gubernur, Bupati dan Wakil
Bupati dan Walikota dan wakil Walikota dalam hal pengisian jabatan wakil kepala daerah, partai politik/ gabungan partai politik berhak mengajukan 2 (dua) orang calon Wakil Bupati melalui Rapat Pari Purna DPRD untuk diajukan kepada Bupati agar memilih salah satu dari 2 (dua) orang calon. Dan setelah dipilih oleh Bupati kemudian diajukan kepada Menteri Dalam Negeri (Mendagri) untuk ditetapkan sebagai Wakil Bupati.

3. Terkait tindakan dari Partai Koalisi atau Partai Pengusung dalamMenetapkan Kebijakan yang Tepat dalam Pengisian Jabatan Wakil Bupati yang Berhalangan Tetap, ada beberapa langkah yang perlu dipertimbangkan oleh Partai Kebangkitan bangsa (PKB) atau partai koalisi pengusung Bupati dan Wakil Bupati (Sri-Edy) terpilih.

Pertama :Menyiapkan kader dari Partai Kebangkitan Bangsa (PKB) yang telah disepakati oleh Bupati Sri Sumarni dan partai koalisi (Partai Amanat Nasional dan Partai Hanura). Tentunya dengan persyaratanpersyaratan yang harus ditanggung oleh calon pengganti baik yang menyangkut komitmen politik maupun 
cost-politik sepanjang dapat dirasionalisasi.

Kedua : Apabila opsi yang pertama tidak dapat dipenuhi, maka langkah berikutnya menawarkan kepada pihak partai koalisi baik dari Partai Amanat Nasional (PAN) maupun dari Partai Hati Nurani Rakyat (Hanura) untuk menyiapkan calon pengganti sebagai calon Wakil Bupati Grobogan dengan persyaratan sebagaimana opsi yang pertama yaitu disetujui Bupati Sri Sumarni dan mengganti cost-politik yang telah dikeluarkan oleh (alm) Edy Maryono. Tentunya penawaran untuk menyiapkan calon pengganti Wakil Bupati kepada partai koalisi lebih mengutakan partai yang kursinya atau jumlah suaranya lebih banyak.

Ketiga : Apabila opsi yang pertama dan kedua tidak terpenuhi, maka perlu mengambil dari pihak luar (non partai koalisi) yaitu dari masyarakat yang independen dan tidak sebagai anggota partai politik atau tidak memiliki keberpihakan kepada partai politik. Seperti pegawai negeri yang berpengalaman (yang dapat diproses pensiun) atau pihak-pihak yang memiliki ketokohan dan pengalaman. Tentunya mereka yang disiapkan telah mendapatkan kesepakatan dari partai koalisi pengusung, utamanya dari
Partai Kebangkitan Bangsa (PKB) sebagai partai yang memiliki hak prioritas.

\section{Saran}

Setelah memahami pengisian Jaban Kepala Daerah dan Wakil Kepala Daerah yang berhalangan tetap dalam sitem ketatanegaraan Indonesia dengan studi kasus di Kabupaten Grobogan, maka disarankan :

1. Bupati dan Wakil Bupati merupakan perpaduan kepemimpinan pada pemerintah daerah, dimana tugas dan tanggung jawab Bupati sebagai Kepala Daerah begitu besar dan berat dalam rangka mensejahterakan rakyat di daerah yang dipimpinya. Maka keberadaan Wakil Bupati menjadi penting demi membantu jalannya pemerintahan di daerah. Karena itu disarankan kepada Dewan Perwakilan Rakyat Daerah (DPRD) Kabupaten Grobogan segera mengusulkan pergantian Wakil Bupati Kabupaten Grobogan.

2. Mekanisme dan tata cara pengisian jabatan Wakil Bupati yang berhalangan tetap telah diatur melalui perundang-undangan khususnya Undang- Undang RI Nomor 10 Tahun 2016, tetapi tidak ada keharusan untuk melakukan pengisian jabatan wakil Bupati yang berhalangan tetap. Maka 
ketika persoalan poltik belum selesai, jabatan Wakil Bupati dibiarkan kosong. Karena itu perlu dibentuk regulasi atau setidaknya melalui Peraturan Menteri Dalam negeri (Mendagri) tentang kewajiban melakukan pengisian jabatan Wakil Bupati bagi yang berhalangan tetap.

3. Bagi partai politik pengusung Bupati dan Wakil Bupati, kususnya Partai Demokrasi Indonesia Perjuangan (PDI-Perjuangan) dan Partai Kebangkitan Bangsa (PKB) segera mengambil sikap bahwa Wakil Bupati sebagai pembantu bupati dipandang sangat penting dalam penyelenggaraan pemerintahan daerah di Kabupaten Grobogan. Karena itu persoalanpersoalan politik agar segera diatasi khususnya yang menyangkut costpolitik baik dalam proses pencalonan maupun hal-hal lain yang berkenaan dengan pengajuan pengganti wakil bupati disarankan untuk segera diselesaikan demi segera diangkatnya Wakil Bupati.

\section{DAFTAR PUSTAKA}

Ananingsih, S. W. (2016). Tantangan dalam Penanganan Dugaan Praktik Politik Uang Pada Pilkada Serentak 2017. Jurnal Masalah-Masalah Hukum,
45(1), 49-57.

Anggraeni, M. (2016). Kedudukan dan Kewenangan Wakil Kepala DaerahDihubungkan Dengan UndangUndang RepubLik Indonesia Nomor 9 Tahun 2015 Tentang Perubahan Kedua Atas Undang-Undang Nomor 23 Tahun 2014 Tentang Pemerintahan Daerah. Universitas Pasundan.

Arrsa, R. C. (2014). Pemilu Serentak dan Masa Depan Konsolidasi Demokrasi. Jurnal Konstitusi, 11(3), 515-537.

Budhiati, I. (2013). Quo Vadis Demokrasi Prosedural Dan Pemilu: Sebuah Refleksi Teoritis. Jurnal MasalahMasalah Hukum, 42(2), 268-273.

Huda, N. (2015). Hukum Tata Negara Indonesia. Jakarta: Rajawali Press.

Meyer, T. (2013). Peran Partai Politik dalam Sebuah Sistem Demokrasi: Sembilan Tesis. Friedrich. Jakarta: Ebert-Stiftung (FES).

Nuraini, S. (2006). Hubungan Eksekutif dan Legislatif di Era Otonomi Daerah. Jurnal Madani Edisi I/ Mei 2006, 6.

Respationo, H. M. (2013). Pemilihan Kepala Daerah dalam Demokrasi Electoral. Jurnal Masalah-Masalah Hukum, 42(3), 355-361.

Safa'at, M. A. (2009). Pembubaran Partai Politik Di Indonesia (Analisa Pengaturan Hukum dan Praktik Pembubaran Partai Politik 1959 - 
2004). Universitas Indonesia.

Soekanto, S. ., \& Mamudji, S. (n.d.).

Penelitian Hukum Normatif Suatu

Tinjauan Singkat. Jakarta: Raja

Grafindo Persada.

Soemantri, S. (2006). Prosedur dan Sistem

Perubahan Konstitusi. Bandung:

Alumni.

Soemitro, R. H. (1982). Metodologi

Penelitian Hukum dan Jurimetri.

Jakarta: Ghalia Indonesia.

Suharizal. (2011). Pemilukada: Regulasi,

Dinamika dan Konsep Mendatang.

Jakarta: Raja Grafindo Jaya.

Wijaya, T., \& Griadhi, I. (2014). Pengisian

Kekosongan Jabatan Wakil Kepala

Daerah Yang Berasal Dari Partai

Politik Atau Gabungan Partai Politik

Berdasarkan Undang-Undang Nomor

12 Tahun 2008. Jurnal Kertha Negara,

2(5), 3 . 